\title{
Infection in exacerbations of asthma: views of different groups of practitioners
}

\author{
C.K. Connolly, N.K. Murthy, R.J. Prescott ${ }^{1}$ and R.M. Alcock
}

Department of Community Medicine, Usher Institute, Medical School, Teviot Place, Edinburgh EH8 9 AG and ${ }^{1}$ Medical Statistics Unit, Medical School, University of Edinburgh EH8 $9 A G, U K$

Summary: A questionnaire designed to elucidate views on the frequency of infection in asthma and its management was circulated to general practitioners, general physicians, paediatricians and respiratory physicians in the north of England. On the whole, general practitioners agreed with the general physicians and paediatricians with respiratory physicians. The generalists, and to a lesser extent the specialists, tended to overestimate the risk of bacterial infection, which was perceived to be a particular risk following viral infection in intrinsic asthma. This resulted in more frequent prescription of antibiotics than is justified by the published evidence. There was a tendency for frequent prescribers of antibiotics to withold corticosteroids. If prescribing habits are to be altered, education will have to be directed at those responsible for acute admissions to hospital as well as at general practitioners.

\section{Introduction}

There is little evidence that bacterial infection is a problem in acute exacerbations of asthma. It probably occurs in less than $15 \%$ of cases. ${ }^{1,2}$ Nevertheless, antibiotics are frequently prescribed, certainly in hospitals. ${ }^{3}$ Viral infections do contribute to asthma in childhood ${ }^{4-6}$ and adult life, ${ }^{7}$ though probably in a small proportion of attacks in the latter. ${ }^{1,4}$ The importance of inflammation in asthma is being increasingly realized. ${ }^{8}$ Other precipitating factors may produce similar signs and symptoms to those of viral infection. ${ }^{9}$ There is no relationship between sputum appearance and infection. ${ }^{2}$

Although inappropriate use of antibiotics is probably rarely harmful in the individual attack or patient, the cost and the implications of unnecessary exposure of bacteria to antibiotics have to be considered. Furthermore, if asthmatics are treated as 'bronchitics' with antibiotics, treatment of infection itself might be regarded as sufficient, and so bronchodilators and corticosteroids might be withheld. ${ }^{10}$ Although the evidence is consistent that antibiotics have little, if any, place in the management of acute exacerbations of asthma, the studies are few, are not based on large numbers of patients,

Correspondence: C.K. Connolly, F.R.C.P., Darlington Memorial Hospital, Darlington, County Durham DL3 6HX, UK

Accepted: 11 March 1991 and the volume of this published work is small in the context of the large clinical problem. ${ }^{2}$ As a preliminary to a possible further study, an attempt was made to establish current opinion and practice in the Northern Region of the National Health Service by means of a questionnaire.

\section{Methods}

\section{Subjects}

General practitioners A one-in-three sample of members of the Northern Faculty of the Royal College of General Practitioners was made by taking every third name from the list supplied by the Faculty.

Consultants All consultants employed in the Northern Region in the National Health Service in the following categories: (a) hospital paediatricians; (b) chest physicians or physicians with an interest in respiratory medicine (respiratory physicians); (c) all physicians with responsibility for acute admissions but excluding the above.

\section{The questionnaire}

The questionnaire, full copies of which are available from the authors, was divided into two sections: 'aetiology' and 'management'. Each section started with a simple yes/no question: 'Do you regard infection as a frequent factor in exacerba- 
tions of asthma?' and 'Do you frequently prescribe antibiotics in the treatment of asthma?' The answers were amplified as described below.

In the first section, possible signs and symptoms leading to a clinical diagnosis of asthma were suggested. Respondents were asked which they regarded as evidence of viral and which of bacterial infection. They were asked which organism was likely to be involved in bacterial infection associated with an exacerbation. The management section requested comments on the frequency of prescription of antibiotics and the signs and symptoms that would encourage the practitioners to use them. Practitioners were asked for an estimate of the chance of success that they required of an antibiotic before they would consider prescribing it. They were also asked whether, in an exacerbation of asthma with purulent sputum, they would prescribe steroids without antibiotics or vice versa.

A reply paid envelope was provided. No identification other than the group to which the respondent belonged appeared on the reply, so it was not possible to send reminders.

\section{Statistical methods}

With the exception of the first question in each section, respondents were asked to express associations as certain, strong, possible or none. In tabulating the results, 'certain' and 'strong' are presented together as positive replies, with 'pos- sible' and 'none' recorded as negative replies. The significance was tested using the original data before amalgamation of these categories. Where questions were unanswered or not relevant, results were expressed in terms of the number of responders to each question. Statistical significance of the associations was assessed by the Chi-squared test for contingency tables, by the Trend test for $2 \times \mathrm{K}$ tables, by the Kruskal-Wallis test, or by use of the Spearman rank correlation coefficients, according to the type of data as described by Bland. ${ }^{11}$

\section{Results}

Replies were received, from 119 of 248 general practitioners $(48 \%), 35$ of 81 general physicians $(43 \%), 14$ of 22 respiratory physicians $(63 \%)$, and 31 of 60 paediatricians $(52 \%)$. Opinions on the frequency of viral and bacterial infection and use of corticosteroids are summarized in Table I. The approach of general practitioners and general physicians was generally similar, particularly with regard to the risk of bacterial infection. All groups thought that bacterial infection which did occur was likely to be secondary to viral infection. Bacterial infection was assessed as most likely in adult intrinsic asthma, where even $43 \%$ of respiratory physicians suggested the prevalence was more than $20 \%$.

Table I The percentage of respondents giving positive replies to questions on the frequency of infection and prescription of antibiotics

\begin{tabular}{|c|c|c|c|c|c|}
\hline & $\begin{array}{c}\text { General } \\
\text { practitioners }\end{array}$ & $\begin{array}{c}\text { General } \\
\text { physicians }\end{array}$ & $\begin{array}{c}\text { Chest } \\
\text { physicians }\end{array}$ & Paediatricians & $P^{\dagger}$ \\
\hline Number & 119 & 35 & 14 & 31 & \\
\hline $\begin{array}{l}\text { 'Do you regard infection as } \\
\text { frequent factor in ex. of } \\
\text { asthma'. }\end{array}$ & 78 & 69 & 64 & 84 & ns \\
\hline Viral infection more likely & 91 & 71 & 100 & 100 & 0.0003 \\
\hline Risk of secondary infection high & 40 & 40 & 14 & 6 & 0.001 \\
\hline $\begin{array}{l}\text { Overall risk of } \\
\text { bacterial infection } \\
>20 \% \text { infection }\end{array}$ & & & & & \\
\hline (a) Childhood asthma & 24 & & & 10 & ns \\
\hline (b) Adult atopic asthma & 31 & 40 & 7 & & 0.08 \\
\hline (c) Adult intrinsic asthma & 50 & 83 & 43 & & 0.001 \\
\hline $\begin{array}{l}\text { 'Do you frequently } \\
\text { prescribe antibiotics } \\
\text { in the treatment of asthma?' }\end{array}$ & 42 & 69 & 29 & 6 & $<0.0001$ \\
\hline $\begin{array}{l}\text { Sometimes prescribe } \\
\text { antibiotics without steroids }\end{array}$ & 92 & 60 & 29 & 63 & $<0.0001$ \\
\hline $\begin{array}{l}\text { Junior staff prescribe } \\
\text { antibiotics more frequently }\end{array}$ & $85^{*}$ & 66 & 79 & 70 & 0.03 \\
\hline
\end{tabular}

* General practitioners with deputies. ${ }^{\dagger}$ Significance levels reported are based on the simultaneous comparison of all groups of practitioners; ns - not significant. 
Purulent sputum was suggested as an indication for antibiotics by more than $80 \%$ of generalists and half of the respiratory physicians (Table IIa). Table III summarizes the influences on prescription in doubtful cases. General physicians were particularly likely to be influenced by previous coloured sputum whilst respiratory physicians were least likely to regard concurrent corticosteroids as an indication for antibiotics. Those who claimed to be frequent prescribers were more likely to regard subacute onset and persistent exacerbations as indications of bacterial infection than the others $(P<0.001)$. Similarly, they were more likely to accept signs compatible with infection as indications for antibiotics (Table IIb), and to prescribe in doubtful cases where there was a previous history of prolonged relapse, of purulent sputum, and when there was concurrent prescription of corticosteroids (Table IIIb).

On the whole, practitioners regarded those parameters which, to them, suggested bacterial infection as indications for antibiotics, independently of whether they were frequent or infrequent prescribers. Consequently, frequent prescribers tended to be the individuals who accepted more variables as indicative of bacterial infection. There was no indication that frequent prescribers were less confident in their diagnoses of infection and so were prescribing 'just in case'. On the contrary, the trend was in the opposite direction. Frequent prescribers tended to require a higher prior probability of infection by a sensitive organism before instituting antibiotics $(P=0.08)$, particularly when intrinsic asthma was diagnosed $(P<0.01)$.

Table II Percentage of respondents accepting each parameter as principal indication for antibiotics

\begin{tabular}{lcccccc}
\hline Respondent & $N$ & $\begin{array}{c}\text { Subacute } \\
\text { onset }\end{array}$ & $\begin{array}{c}\text { Persistent } \\
\text { deterioriation }\end{array}$ & $\begin{array}{c}\text { Purulent } \\
\text { sputum }\end{array}$ & Fever & $\begin{array}{c}\text { Raised } \\
\text { WBC }\end{array}$ \\
\hline
\end{tabular}

(a)

$\begin{array}{lrccccc}\text { General practitioner } & 119 & 16 & 66 & 82 & 57 & 61 \\ \text { General physician } & 35 & 19 & 65 & 83 & 80 & 71 \\ \text { Respiratory physician } & 14 & 8 & 7 & 57 & 50 & 29 \\ \begin{array}{l}\text { Paediatrician } \\ P^{*}\end{array} & 31 & 3 & 48 & 70 & 23 & 44 \\ & & 0.0012 & 0.0003 & 0.12 & 0.0001 & 0.03 \\ \text { (b) } & & & & & 78 & 74 \\ \begin{array}{l}\text { Frequent prescribers } \\ \text { The remainder }\end{array} & 82 & 23 & 76 & 89 & 40 & 48 \\ & 117 & 8 & 47 & 72 & 40 & 0.0009\end{array}$

* Significant levels reported are based on the simultaneous comparison of all groups of practitioners.

Table III Percentage of respondents accepting each parameter as an indication for antibiotics in doubtful cases

\begin{tabular}{lcccc}
\hline Respondent & Concurrent & $\begin{array}{c}\text { Previous history } \\
\text { of prolonged } \\
\text { steroids }\end{array}$ & $\begin{array}{c}\text { Previous history } \\
\text { relapses }\end{array}$ & $\begin{array}{c}\text { coloured } \\
\text { sputum }\end{array}$ \\
\hline
\end{tabular}

(a)

\begin{tabular}{lrccc} 
General practitioner & 119 & 62 & 86 & 58 \\
General physician & 35 & 38 & 76 & 76 \\
Respiratory physician & 14 & 29 & 29 & 57 \\
Paediatrician & 31 & 42 & 57 & 33 \\
$P^{*}$ & & 0.011 & $<0.0001$ & 0.007 \\
\hline
\end{tabular}

(b)

$\begin{array}{lrccc}\text { Frequent prescribers } & 82 & 64 & 91 & 72 \\ \text { The remainder } & 117 & 44 & 64 & 48 \\ P & & 0.012 & <0.0001 & 0.002\end{array}$

* Significant levels reported are based on the simultaneous comparison of all groups of practitioners. 
Those most likely to prescribe antibiotics without corticosteroids, were also those who were most confident that signs of inflammation indicate bacterial infection requiring treatment, placing particular emphasis on green sputum $(P<0.01)$. Thus there were more frequent prescribers in this group $(31 \%$ vs $14 \%, P<0.05)$. Nevertheless frequent prescribers represented only $47 \%$ of those who might withhold steroids in the presence of the signs of inflammation.

Nearly all respondents appropriately chose ampicillin or amoxycillin, as the majority thought that Haemophilus influenzae or Streptococcus pneumoniae to be the most likely organism.

\section{Discussion}

Although many patients and doctors blame exacerbations of asthma on infection, objectively, infection is only demonstrated to be a factor in about $10 \%$ to $15 \%$ of adult patients. ${ }^{1}$ It is more frequent in childhood, occurring in up to $42 \%$ of cases at normal times, ${ }^{12-14}$ and in as many as $85 \%$ at times of epidemics. ${ }^{14}$ No study has demonstrated a relationship with bacterial infection, and the routine use of antibiotics in the hospital management of acute asthma is unhelpful. ${ }^{2}$ Nevertheless, antibiotics are frequently prescribed in exacerbations by many doctors.

In this survey, frequent prescribers, particularly those who gave antibiotics without corticosteroids, were the most confident that the signs of inflammation equated with infection, and hence prescribed antibiotics. This suggests that prescribers justified antibiotics, not as a precautionary measure, but as an appropriate treatment after a diagnosis of infection had been made on clinical grounds.

The replies were, on the whole, consistent within the different groups of practitioners. The generalists were more likely to equate the signs of inflammation, particularly purulent sputum, with infection. Paediatricians rightly regarded virus infection as a frequent problem. Respiratory physicians overestimated the risk of bacterial infection less than general physicians. Even so, the majority of both the respiratory physicians and paediatricians, do accept purulent sputum as a strong indication for antibiotics, despite the published data. Most clinicians appear to justify antibiotics on the grounds of risk of secondary infection, particularly in adult intrinsic asthma.

This questionnaire referred to patients in whom the diagnosis of asthma was established. No enquiry was made with regard to the treatment of 'wheezy' bronchitis, let alone acute or chronic bronchitis, and so the fear expressed by Wardman et al. ${ }^{10}$ about misdiagnosis was not covered. With this caveat the answers to this questionnaire only suggest a small amount of underprescription of corticosteroids as a result of the use of antibiotics, in part because frequent prescribers of antibiotics are more likely to regard treatment with corticosteroids as itself an indication for antibiotic therapy.

The relatively small study, ${ }^{2}$ which suggested that bacterial infection is not important in adults, though in itself satisfactory, probably does not carry sufficient weight to deliver its message effectively. Possibly, the time has come for a further large scale study of the whole of a defined population in and out of hospital to confirm its conclusions. Education of non-specialists, if felt desirable, must be directed at those with responsibility for acute admissions to hospital as well as general practitioners.

\section{Acknowledgement}

Our thanks are due to Ms Claudia Kriepl for undertaking most of the data processing.

\section{References}

1. Hudgel, D.W., Langston, L. Jr, Selner, J.C. \& McIntosh, K. Viral bacterial infections in adults with chronic asthma. Am Rev Respir Dis 1979, 120: 393-397.

2. Graham, U.A., Milton, A.F., Knowles, G.K. et al. Routine antibiotics in hospital management of acute asthma. Lancet 1982, i: $418-420$.

3. Bucknall, C.E., Moran, F., Robertson, C. \& Stevenson, R.D. Differences in hospital asthma management. Lancet 1988, i: $748-750$.

4. Sherter, C.B. \& Polnitsky, C.A. The relationship of viral infections to subsequent asthma. Clin Chest Med 1981, 2: 67-78.

5. Minor, T.E., Dick, E.C., Baker, J.W. Rhinovirus and influenza type $A$ infections as precipients of asthma. Am Rev Respir Dis 1976, 113: 149-153.

6. Minor, T.E., Baker, J.W., Dick, E.C. et al. Greater frequency of viral respiratory tract infection in asthmatic children as compared with their non-asthmatic siblings. J Pediatr 1974, 85: 472-477.

7. Beasley, R., Coleman, E.D., Hermon, Y. et al. Viral respiratory tract infection and exacerbations of asthma in adult patients. Thorax 1988, 43: 679-683.

8. Hargreaves, F.E., Ramdale, E.H., Kirby, J.G. \& Byrne, P.M. Asthma and the role of inflammation. Eur J Respir Dis 1986 147: $16-21$

9. Empey, D.W., Laitinen, L.A, Jacobs, L. et al. Mechanisms of bronchial hyperactivity in normal subjects after respiratory infection. Am Rev Respir Dis 1976, 113: 131-139. 
10. Wardman, A.G., Binns, V., Clayden, A.D. \& Cooke, N.J. Diagnosis and treatment of adults with obstructive airways disease. Br J Dis Chest 1986, 80: 19-21.

11. Bland, M. An Introduction to Medical Statistics. Oxford University Press, Oxford, 1987, p. 270.

12. Horn, M.E.C., Brain, E.A., Gregg, I. et al. Respiratory viral infection and wheezy bronchitis in childhood. Thorax 1979, 34: 23-28.
13. Minor, T.E, Dick, E.C., De Meo, A.N. et al. Viruses as precipitants of asthmatic attacks in children. JAMA 1974, 227: 292-298.

14. McIntosh, K., Ellis, E.F., Hoffman, I.S. et al. The association of viral and bacterial respiratory infections with exacerbations of wheezing in young asthmatic children. $J$ Pediatr 1983, 82: 578-590. 